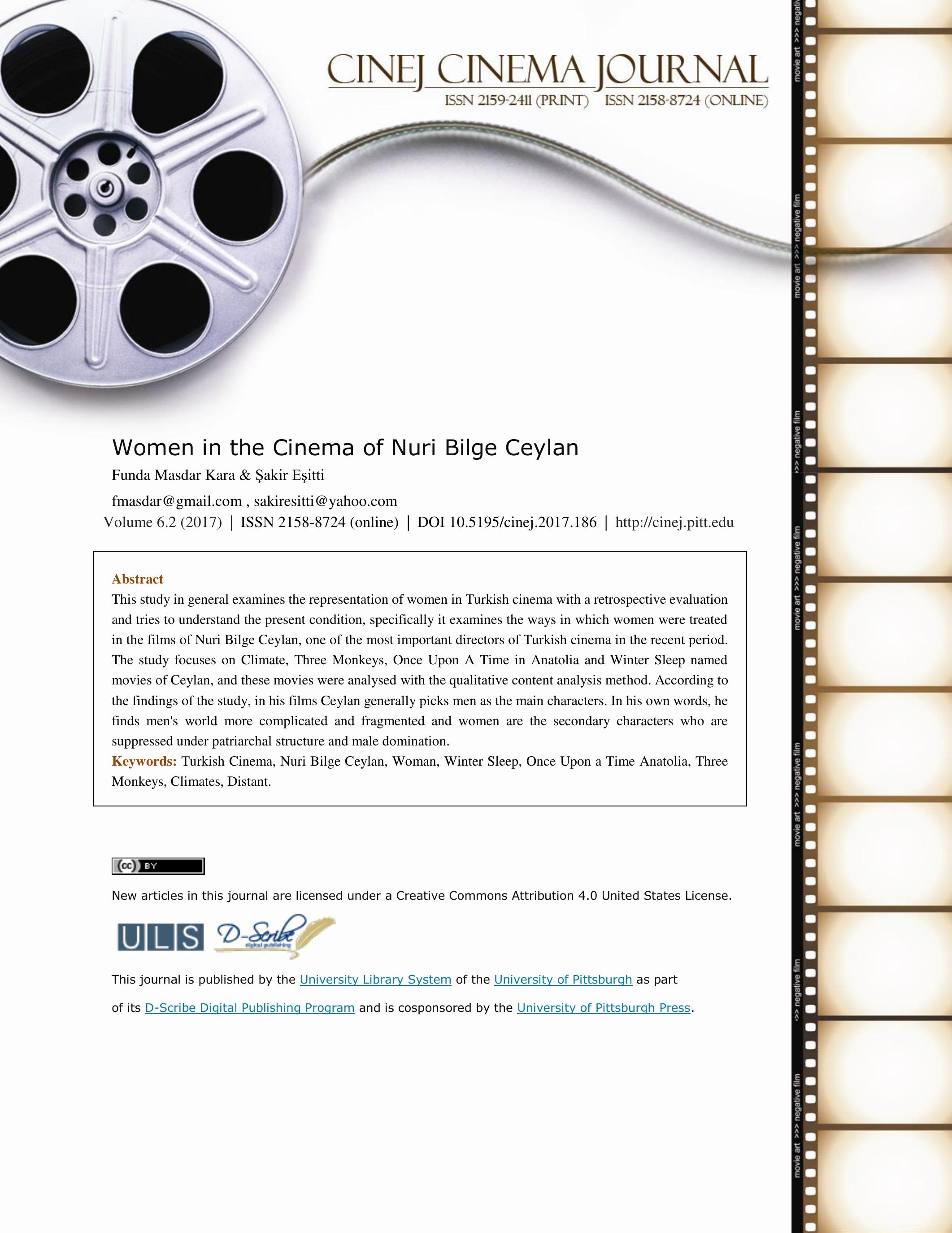




\section{Women in the Cinema of Nuri Bilge Ceylan}

\section{Funda Masdar Kara \& Şakir Eşitti}

\section{Introduction}

The art is a reflection of the life and the woman is one of the universal themes of the art that is inspired by the life. If the world art is examined in the flow of historical system, it is evident that, in the frame of historical and structural conditions, each era and cultural formation include women in pieces of art. Cinema, being the representative of the artistic language of the civilization of technology, is the art form which reflects and is fed by the life most, as a need and result of both being a visual art form and its function as media. While witnessing the life, cinema has the projection of gender perceptions of various cultural structures in its memory. When we look at the history of Turkish cinema, we see that it is shaped in the framework of political, social, economic and cultural changes and transformations. Similar to these phenomena, Turkish cinema too pass through a fluctuating transformation process. In these transformation process, the woman in the cultural codes of the society, was screened for a long period with her objectified identity without crossing the lolita image of the patriarchal structure. In this context, presentation of woman as an objectified identity in the media, especially in the contents of cinema and television, may contribute to 'the legitimization and reproduction of unequal gender roles' in a society (Iş1k and Eşitti 2015, p. 121).

There are a lot of movies in the Turkish cinema which treat women as they reflect the socioeconomic and cultural structure of Turkey and become the main factors of the thematic pattern under this structure. Especially in the periods when the phenomena of actor and actress were quite central, scripts were fairly designed for actresses. Women took place in the Turkish cinema not only as thematic values, but also as visual values. When the strong Anatolian woman was portrayed 
in the rural life, the emotional identity of the woman was always the main focus. The woman became an indispensable element both as an object of love and of esthetics. No gender conflict was evoked. Socially constructed gender roles were supported and even reproduced as they were presented as the natural and present gender structure.

The new atmosphere created due to the 1961 constitution paved the way for the taboos in the cinema as it was in many other fields, and the films which overlap more with the reality of the country were produced especially in the examples of the socialist-realist cinema as well as the revolutionist cinema. In many films that were produced in the period from the liberal atmosphere of the new constitution to the 1980 coup d'état and the censorship period which occurred as a product of the 1982 constitution, women appear to be taken into account more realistically as well as the other elements of the social structure. However, rather than criticizing or alleviating the situation in which the woman was placed, it is a kind of reality that approves this situation and helps its reproduction. The main woman themes in the rural areas are generally about the loneliness, disclosure of hidden sexual emotions, passiveness and dependence, the silent and desperate situation, forbidden relationships and challenges of women under traditions. Moreover, the effects of men such as bullying, determining the faith of women, oppressing over women and forcing their own sexual passions to women are mentioned, too. It is not very heart-warming either in the movies which focus on the urban woman. Even in the cities, all the codes of the patriarchal structure evaluate women by restraining them in specific role patterns, irrespective of their being housewives or working women. They impose gender discrimination and all the oppressive elements of patriarchal structure. Despite all the lumpen, bully, suffering and erotic woman type castings, the main purposed themes are those that are female and feminine at home, a sexual object at bars and nightclubs, but honorable women when they step off the stage. For this reason, when 
the femininity and sexuality of the woman is presented, in order to reflect the social structure, the masculine women typecasting is overlapped with this femininity. As Soykan states, "...in a social structure and understanding that does not equate woman with the man at the same level and tries to suppress her whenever possible, the movies in which the women are shown as confident, powerful and aggressor with an affectation of male(ness), distort the issue of woman and refer to wrong images" (Soykan 1993, p. 69).

Women, who are the indispensable image of melodrama narratives of Yeşilçam Cinema which is called to be classical always appear as the silent wives or devoted mothers. These concepts which somehow validate the patriarchal structure are at the same time the representations of women in Yeşilçam cinema. The model of devoted woman which is the role of the mother that the society approves is also approved by the cinema. The basic conditions of being a happy woman are identified with these attributes. The women who sacrifice for their loves, who keep silent in any circumstances, who learn to desire the men who desires them, who in short accurately behave as the patriarchal structure impose upon them are the transformed, changed, right and approved women of the melodrama cinema. Thus, melodramas are conceived as feminine forms. They, via this way, reproduce and legalize the gender inequality. "Melodrama movies form their narrative on the basis of -being woman- and they bear an important function in adoption of social gender patterns, by producing-reproducing the meanings of being a woman. Even though woman are housewives, singer or teachers, the melodrama movies teach them how to be a woman" (Akbulut 2008, p. 353).

The identity crisis, problems and passions of women began to take part in the changing political framework of the 1980s. While women were sometimes portrayed with their intellectual, marginal and bourgeois habits, dreams, hallucinations and depressions were prioritized rather than the reality of the problems. Depressions were almost idealized and, the most special problems were 
focused in the theme of problematics of woman. The feminist woman typecasting emerged in the 1990s, the woman that appeared as gallery manager, author and painter was portrayed as conscious of gender but in depression of loneliness. The intellectual feminist woman was presented as living in the city, sexually dissatisfied and unable to overcome middle-age crises. With this presentation, an ideological approach was adopted that almost wanted to prove the insolubility of the feminism and pointed out the importance of the pure love in contrast to this insolubility.

Cinema is nourished by the cultural, political, economic and social values of the society where it was produced and it is shaped by these values. When we look at the history of the Turkish cinema, it is apparent that periods are differentiated in relation to these values, and film production is shaped according to these periodical differentiations. In the 1990s, Turkish cinema experienced a revival. Changing social dynamics, the speed of the spread of technology, domestic and international financial supports, involvement of new people who are interested in cinema and who want to make films led to this revival. New quests replaced the concern of finding audience. New themes were taken into account. Along with this, a new generation involved in cinema who tried new types of expression, aimed to establish distinctive cinema language and succeeded it. Directors such as Derviş Zaim, Reha Erdem, Yeşim Ustaoğlu, Zeki Demirkubuz and Nuri Bilge Ceylan are the important figures of the new generation. The most important feature of the new directors is that their movies provides our cinema with new dimensions. Among these directors who has distinctive languages of narrative, Nuri Bilge Ceylan, managed to become the most discussed and mentioned director with his simple and realist narrative, tasty visual presentations and especially his international success.

In this study, it is aimed to discuss the forms of woman's reflection in the cinema of Nuri Bilge Ceylan who approaches the realities of life in odd corners with a plain and modest narrative. 
Since women are almost not positioned in directors's movies Koza (Cocoon), Kasaba (Small Town), Mayıs Sıkıntısı (Clouds of May) and Uzak (Distant); the study focuses on Ceylan's İklimler (Climates), Üç Maymun (Three Monkeys), Bir Zamanlar Anadolu'da (Once Upon a Time in Anatolia), Kış Uykusu (Winter Sleep) and the movies are studied with the method of qualitative content analysis. The aim of the study is to be able to reveal to what extent the role and the importance of woman in the cinema of Nuri Bilge Ceylan overlaps the overall formation of Ceylan's cinema.

\section{The Cinema Of Nuri Bilge Ceylan}

Nuri Bilge Ceylan attended many festivals including Cannes Film Festival with his first movie Koza (1995). He made his first full-length film Kasaba in 1997 and he was awarded at various festivals including Berlin Film Festival Caligari Prize for it. Mayıs Sıkıntısı, which was made in 1999, won many prizes as well, yet the director had the most repercussive success with Uzak in 2002, when it was awarded as the best male actors with both leading male roles and jury prize in Cannes. His Cannes adventure became consistent with 2006-made İklimler (FIPRESCI prize), 2008-made Üç Maymun (the best director) and 2011-made Bir Zamanlar Anadolu'da (Grand-Prix award) and made a great mark in the world cinema. Especially the Palm D'or prize with his last film Kış Uykusu in 2014, indicated the distinctiveness and the quality of Ceylan's cinema, and such a successive success made him the most successful filmmaker in the country and the best representative of the Turkish cinema in the international sphere. According to Pösteki, Nuri Bilge Ceylan addressed to his audience deeply and silently with his simple narrative and modest display, and with his limited opportunities, he brought a different vision and color to the Turkish cinema (Pösteki 2005, p.44). Ceylan, one of the pioneers of the independent cinema, used modernist cinematic techniques in contrast to classical narrative structure, with low budget films, without 
concerning the box office and refusing all the elements imposed by popular cinema. Ceylan picked his themes from the life, and simple details of life indeed; and made stories stemming from his own life. He states the importance of this in the interview with Sonsuzkare magazine in May 2003: I am interested in some themes like everybody else, however I do not give a great importance to the theme. Every theme can be filmed. My belief that you can make the best film even from fig seeds did not change. A theme which seems simple and plain at first glance, surprisingly starts getting changed and deepened if we spare some time and (even sluggishly) keep looking at it. Everything in the world is full of miraculous details. Look at the ground whenever you sit somewhere, look at the little insignificant piece of earth. If you get closer and look it again, you see ants and insects there. If you keep looking at the same area for a long enough time, in this insignificant soil, you see lots of challenges, relations, wars that are not so different from the ones between people. The universe hosts details which, with its slightest part, deeply occupy human's mind. Therefore I do not understand the complaints about the lack of themes in this miraculous world, every slightest part of which fosters that much of curiosity and astonishment (Ceylan 2003).

Nuri Nuri Bilge Ceylan created his own personal cinema by taking part in all of the films and every step of them (Producing, directing, scriptwriting, acting, editing) and with this style and low-budget films, he positioned himself in opposition to the commercial cinema. Ceylan, who stated that he can make a film about every theme also said in the interview with the Sonsuzkare magazine that, the success is related to the narrative style rather than the theme.

Yet the feature that distinguishes an artist is his style of dealing with the theme. Remember Nietzsche's famous quote: There are no phenomena but just interpretations. What makes Van Gogh a great artist would not be his themes. The element which makes a theme convincing and have a place in our soul is the way it is interpreted. When we are told something, the voice, expression, speed and look of the narrator, the points of stress and the point where we are 
positioned are influential and the same aspects are valid for the cinema as well. Each narrator creates a form with the aim to create an impact on the audience. This form consists of elements that the narrator believes that have impact on him/her. A person who gets angry when the important points are heavily stressed in the narrative, naturally tries to avoid it when he/she narrates something. Therefore it may be said that I am a little bit focused on wording. Yet at the same time it may be said the opposite is true. Sometimes I feel that everything happens by itself. When I am about to film a scene that I wrote, there are not very much options. The situations that may provide with endless options like the position of the camera, the objective on it, or the length of a plan appear in front of me with only one option. I do not make very much alternative shooting. I frankly do not know where the feeling that the scene must be shot form that exact point with that exact style stems from (Ceylan 2003).

Ceylan shot his first films with a minimalist understanding and includes almost all aspects of this form in his films. Preference to use amateur players, not to use effect elements such as dialogue, voice and music, to maximally functionalize setting and other objects, to use long shots (with slow rhythm) and generally constant depth of field which plan scenes where the camera angles are deliberately stable are the main features of minimalist cinema. The director dives into a new quest with Üç Maymun (2008) and prefers to use a new form between minimalist/modern narrative and classical/traditional narrative. Along with the use of professional player, he changes the use dialogues, another pattern of the accustomed cinema of Nuri Bilge Ceylan. The player preference and the increase in the dialogues in this movie -which showed a better performance in the box office compared to his other films- was reflected to his last two films as well. In his last film, Kış Uykusu, the use of dialogue is more intensive compared to all the other films. The director states the relation between dialogue and the professional player as such: 
When you work with an amateur player, you have to match your dialogues according to the player. But if you want the player matches oneself to the written dialogues, professionals are better at it. Amateur player are not so good at it. In the last film, we elaborated on the scriptwriting; dialogues as well. Almost everything that gave a feel of improvisation was written beforehand. There were such scenes that, I could not even tolerate the change of a single word. Therefore, it would be better to work with a professional player (Ceylan 2011).

Ceylan managed to go out of the existing cinema understanding with his minimalist film approach and original narrative; studied human with one's all obscurities and mysteries by handling the individual's concerns, experiences, and attitudes towards the changes they face, dead-ends and despairs. He gave the audience the opportunity to watch films beyond usual patterns and brought a new perspective and acceleration to the Turkish cinema.

\section{Women in the Films of Nuri Bilge Ceylan}

In the cinema of Nuri Bilge Ceylan women generally appears as the complementary element in the dimension of male-female relationship. When it is considered that his first three films, Koza, Kasaba and Mayıs S1kıntısı were made from the real-life stories of the director, it may be said that, in these movies, women were placed as shadowy elements, in relation to the positioning of the women in their own lives or to the director's personal perspective. In his later films, in the stories which were based on the events structured around the male character, women appeared with the same perspective. In Ceylan's films, it is obvious that the events develop and flow around the male

character. However, the director who mentions the life itself in his movies, includes women to extent which overlaps the reality of the story, since he does not have a viewpoint that stresses the 
woman, prioritizes women's problems and conveys a concern of message about women. In his own words, he does not show favor to women:

Generally, I do not want to believe that woman has a template place. I hope that, as the man does not have a place inside the "limits that are decided beforehand", the woman does not have that either. She should take a place according to the position in the story and her character. So it depends on the films. However, if it is considered that in general I am more pitiless towards the male characters, it may be said that I place a little bit more importance to them - the male characters. The male personality is divided into many parts, therefore they are more problematical. This makes them more appropriate to reflect he complex issues of life. Women's souls are more balanced, yet it does not mean that there is no tempest in there. I cannot make films through "given" facts and "committed" truths. I am a kind of person that tries to re-interpret the life according to himself, requestioning and starting from the zero-point all the time. Even though I flounder around. Nevertheless I do not show favor to women for the reasons such as that "there is a problem of woman rights in Turkey", or "women are victims in this country (Ceylan 2011).

It is apparent that, in the cinema of Nuri Bilge Ceylan, when women is of concern, like many other elements, we should have different expectations and evaluate it with a different perspective. In Koza, the female character appears in old, estranged couple. The distance of the old couple's relationship is reflected with this estrangement. In Kasaba, women (mother and the grandmother) appear as ineffective, silent and distant elements rather than actively participating in the events, as if they do not exist. In his next film, Mayıs S1kıntıs1, his mother acts. The director, in the mother-father-child triangle, presents a theme of warmhearted, naive, wise mother who loves herself and the life itself. Despite this sincere and warmhearted perspective, the woman is not actively involved in the men's world in this film either. Father-son relationship is more intense than that of mother and son. The film, Uzak which brought the director the main international success and fame, represents a pay-off of Ceylan with himself. The film presents the urban-rural 
dichotomy over two male character, women characters appear when needed and they do so, as in the form and part as they are placed in the men's world. The distance is not just the title of the film but also the element between men and women. Nilay Ulusoy reflects the women in Uzak: "The character Mahmut, while facing with his own rurality through Yusuf, witnesses the distance between himself and his one-night-stand lovers whom he sent back to their homes with tears, his ex-wife that he killed a part of whom because of his lack of love and sent far away, and his mother whom he does not wanted to come close in her death-bed. Yusuf on the other hand, cannot come closer with the girl he follows all the time. The only way of communication that he feels safe is peeping the young girl." (Ulusoy 2011).

In Uzak, even though in different forms, woman is an object of desire for both characters. Yusuf's following a girl in the street and harassing her in the subway is the expression of his sexual problems. On the other and, his inability to form to communicate with the girl he met in the block is the indicator of his naiveté and shyness. Similarly, Mahmut who sometimes fulfills his sexual needs by watching porn, stands at a distance when his wife is at stake and reflects the projections of the rural over him. That he behaves the women he slept with as he does not know them in other circumstances is an indicator that women are nothing than a sexual object for him. In terms of its theme, Uzak is a reflection of estrangement. Therefore there is an estrangement in relationships dimension as well and women is affected from that in terms of the dimension of man-woman relationships. It may be said that Ceylan established a successful positioning in the context of two male characters' view and perception of women. It is inevitable that self-contradictory individual has also contradictions in one's relations with the opposite sex and therefore the problems emerge in one's positioning in life. 
In İklimler, in which Ceylan's wife Ebru Ceylan played, Bahar and Serap, appear as two female character occupying a place in Isa's life. According to Rekin Teksoy, the film "deals through a summer, an autumn and a winter with the ill-communication between a man and a women who do not have anything left to say each other. The movie which presents a visual esthetics, has a poetic narrative thanks to extraordinary nature displays and connotes Antonioni's male-female relationships from the beginning to the end, is the most mature example of Ceylan's simple narration who is one of the most prominent representatives of creative director cinema in Turkey" (Teksoy 2007, p. 103 - 104). In the film, Bahar is the lover of Isa, the male character. She is younger than him. She appears as someone who is taken for granted by Isa to be always close to him, as one side of the fluctuating relationship which is determined by Isa's demands. Bahar, who tries to break the shells of Isa, is hopeful despite all the distance. Second female character, Serap is just a sexual object for Isa although she seems a more straight head woman compared to Bahar. The two female characters are positioned in accordance with the demands and choices of Isa. The man could easily broke-up and make-up with them according to his will, could come close or have a distance with them or render them worthy or worthless. Both women are the embodied version of man's vision to the women, the relationship and love in his life. They are the reflections of Isa's dichotomy. According to Eren, "...on the one hand, creation of the character Serap, who is older than Bahar, as an attractive and confident woman with his assertive clothing and style; on the other hand picturing Bahar as an unpredictable, spoiled girl despite her being more modest with her physical appearance and style is the expression of the two opposite sides of his two different souls, indecisiveness, obscurity of demands from life" (Eren 2008, p. 73). 


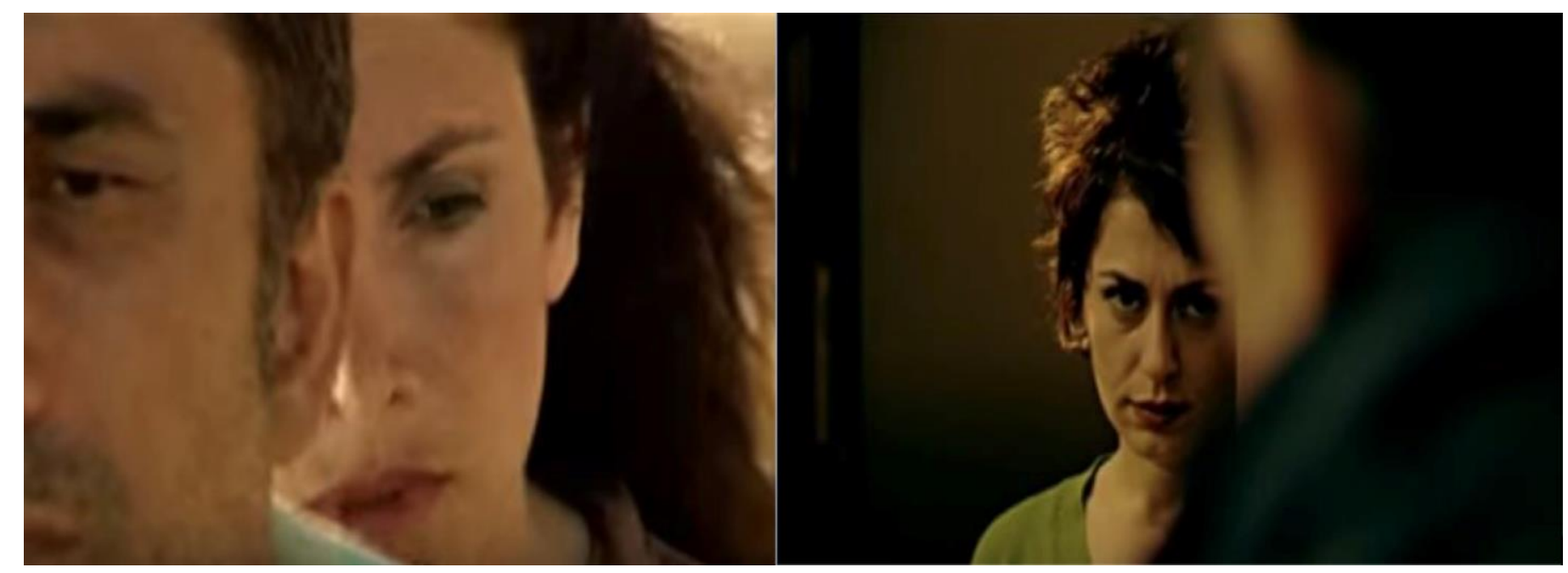

Image 1 and 2: İklimler (2006)

In that sense, even though women take more parts in İklimler compared to others, the perception that they are weak and under control of men is created as well. Ceylan prefers to narrate the reality of the life with a simple language and he reflects women who are a great part of life as they are in their relationships and conflicts. In a sense, the patterns of women in his films are not so different than those in real life.

Director's 2008-made Üç Maymun tells the story of a family who struggles to stand together despite all the things they know, hear and see. In the film, in relation to the female character Hacer's forbidden love, the dilemmas he fell in against her husband, secret lover and son; and the psychological and physical violence by the three men are viewed. However, this film offers more than this simple narrative to the audience and tells the story of lives in insecurity, lies and sins, the sinister life and the multi-faced people. In the film, there is no communication or love in the family affairs and the film focuses on the process and consequences the family experiences after the father Eyüp takes the blame of his boss Servet's crime in return for money and is put in jail. Events develop as the son İsmail makes his mom (Hacer) go to Servet's office to ask for money 
in order to start up a business. In Seyhan Aksoy's words, Hacer is a traditional woman, and even a self-sacrificing mother until he goes to Servet's office to ask for money (Aksoy 2011, p. 244). Servet is a powerful and rich man. This power is very influential for Hacer and she is hooked by a passionate love. Later, the son and the father learns the affair. After the father goes out of jail, Servet is killed by İsmail. Although Hacer appears as the only guilty and at the center of the crime, in fact men are in the center of both crime and story. The character of father, who gets jailed for taking the blame of another -rich and powerful-man and the character of son who sends his mother to the rich and powerful man's office in order to ask for money are the two characters who mainly shapes the women character who shows up alone and sad during the entire film.

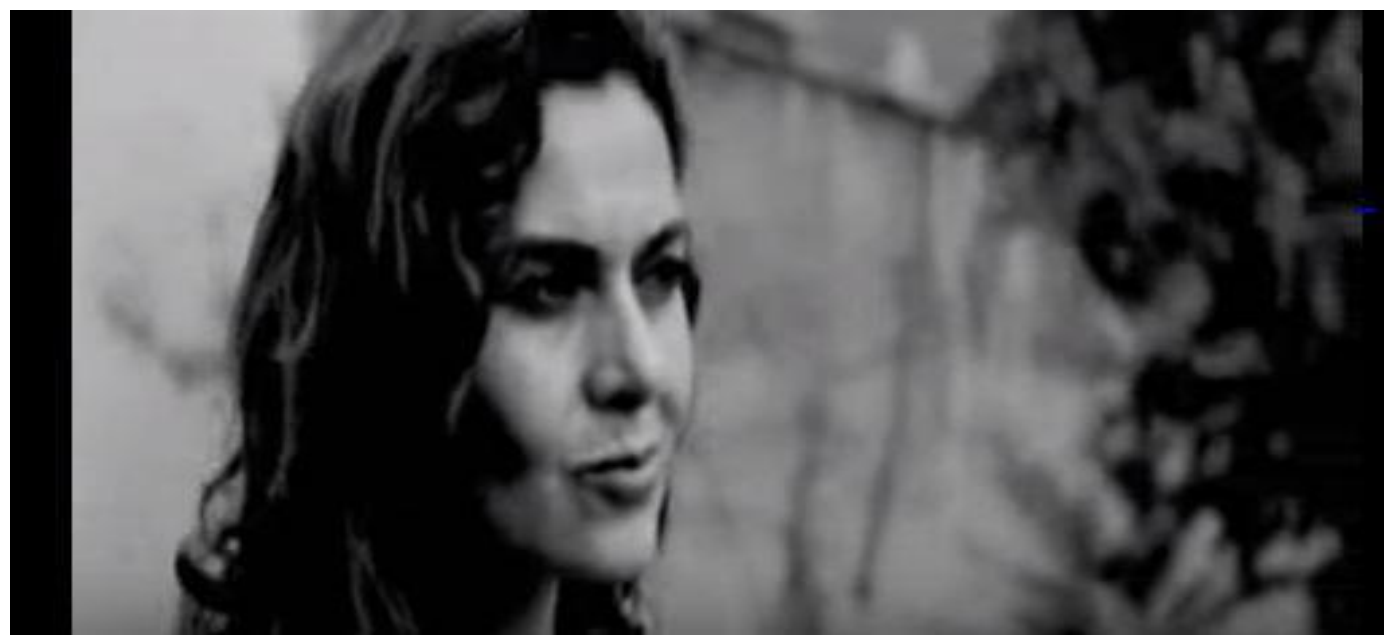

Image 3: Üç Maymun (2008)

In Üç Maymun, the woman is no more than someone who secretly meet and occasionally have sex. Woman's relation with İsmail is a relationship based on self-interests rather than a mother-son relationship. She seeks the attention and love which she does not get from his husband or son, from Servet, and even she seeks for a reciprocal relationship. As long as she remains in her traditional codes, the female character in the film is unattended, loveless, and receded in the background in the men's world where the money and power rules. Whenever she crosses the limits on these codes, she is sinful, dangerous and guilty. 
The female character in Üç Maymun is traditional self-sacrificing mother and wife until she goes to Servet's office. When she encounters the power in the office, she appears with her frustration and desire of power. Her secret love affair is first realized by his son İsmail and she is punished by İsmail, the first male character to do so, with physical violence. Later, she is exposed to physical violence in the bed scenes by another male character, her husband Eyüp after he goes out of jail. In both cases, the woman is weak and powerless, the powerful and the authority is the male. Finally Servet writes her off by threatening her. Hacer again is the begging one; she is weak and powerless one. Ceylan, by getting overwhelmed by male domination, power of the money and her weaknesses, involves in a relationship which abandons the traditional roles and which is not approved by the society. However, in both cases, the passive woman appears as she is smashed in front of the audience, is exposed to psychological and physical violence under male domination.

The story of a group of men and a suspect who hit the road to search for a buried corpse is told in Ceylan's another film, Bir Zamanlar Anadolu'da. In fact the film is like an arena of the weaknesses and power struggles of men from different professions and status. Another dimension of this struggle among them is the inner struggle that each has in himself. In Bir Zamanlar Anadolu'da, suspect, prosecutor, crime and the punishment are presented with men, women are not involved either to these spheres or the spaces where the story takes place. The male characters are successfully pictured with their professions, fears, lies and secrets whereas it is not the case for the women. Two women appears in the film who are very obscurely pictured. However the meaning installed on them is very important. The first female character is village chief's young and beautiful daughter Cemile, and the other is Gülnaz, the victim's wife. 


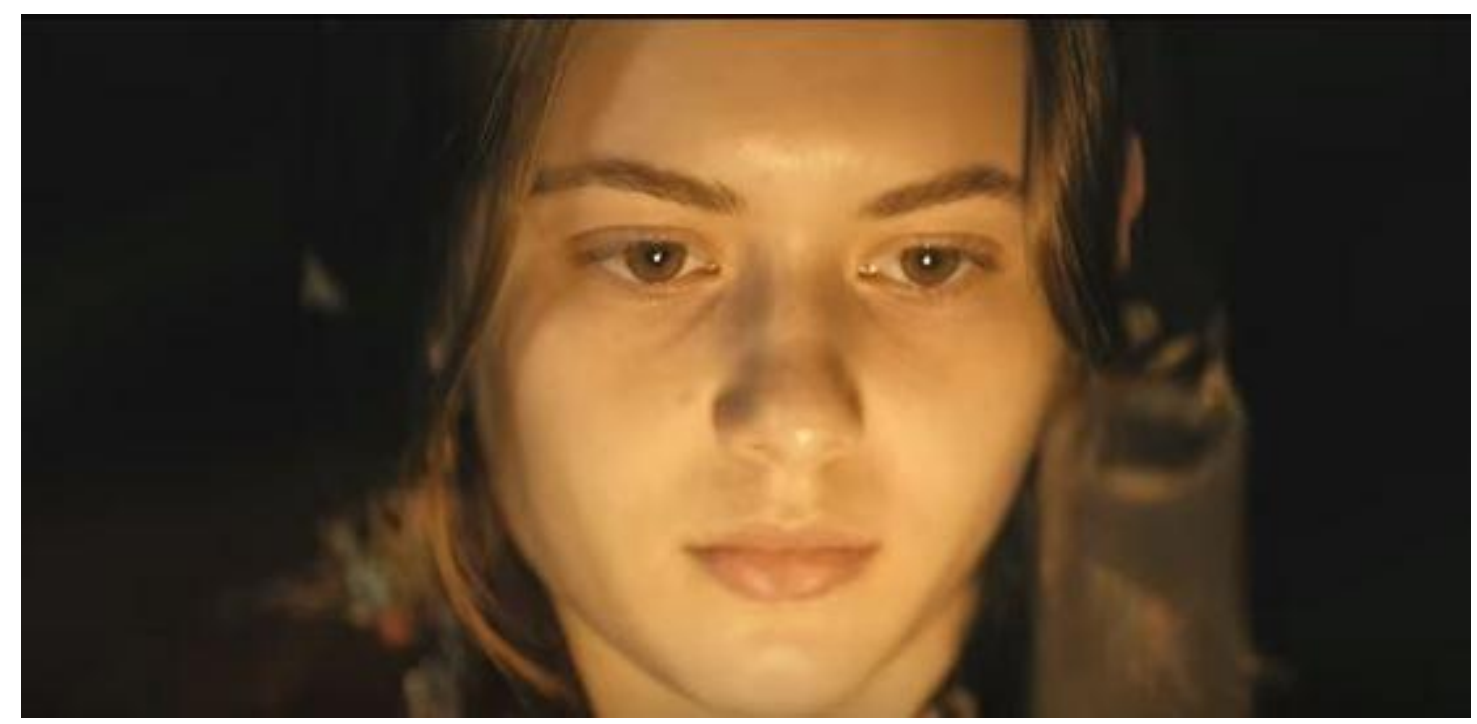

Image 3: Bir Zamanlar Anadolu'da (2011)

Chief's daughter Cemile is portrayed in slow-motion when she picks up the laundry; she resembles an object of display in the men's world. She seems like an angel when she brings tea to the guests. This young and beautiful girl is, so to say, the example of innocence and purity; she is so pure and innocent that, the suspect Kenan feels regret and cries. She replaces the victim's conscience.

Other female character in opposition to young and beautiful Cemile is Gülnaz who waits questionably in the hospital to identification of the victim. The suspect commits this crime for her. Gülnaz's facial expression and swinging feet in black socks and black high heels connote the lost innocence, in opposition to Cemile's innocent, almost lustrous face under gaslight's lighting. The police chief indicates that there are always women behind great crimes according to his experiences and says, "Wherever you see a chaos, then look for for women or an issue related to women there. Frankly I do so for years and I was never false". Police chief's words supports Parsa and Akmeşe's claim that "women who are seen rarely in plotline yet secretly hidden in the 
background, as the main theme" and indicates women's position in the film (Parsa and Akmeşe 2012, p.10).

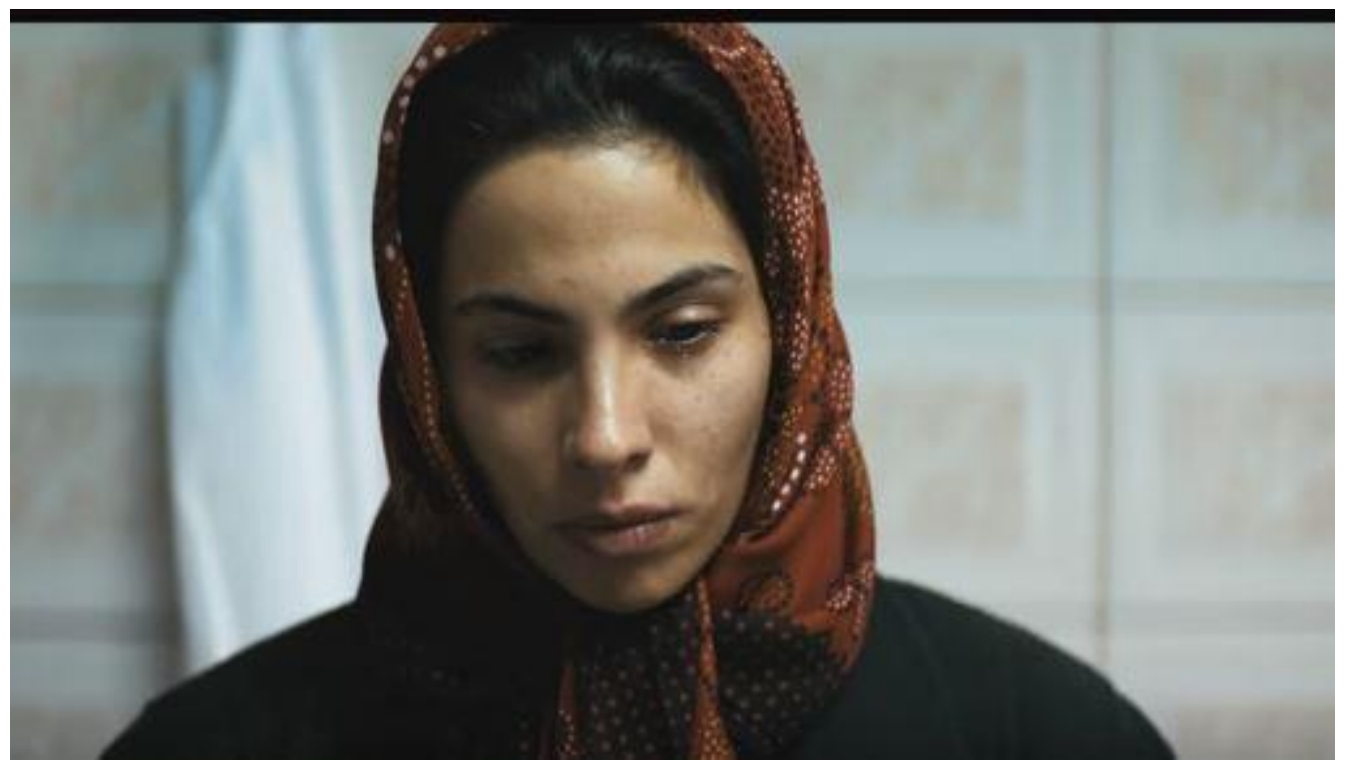

Image 4: Bir Zamanlar Anadolu'da (2011)

Director's last film, Kış Uykusu, which was awarded Palm D'Or, draws attention with professional players, nearly three and a half-hour length, continuously flowing dialogues that resembles a catch-run play, and sometimes black humor that leaves a smile in the faces. The film tells the story of life of a former theatre actor Aydın with his sister Necla and his wife Nihal in a small hotel. The main character is male. The two female character who accompany the man and the other characters are mainly positioned to clarify the situation of the intellectual man. While it seems that there is a criticism of intellectuals over male character, the film also successfully deals with themes such as class conflict, encounter, loneliness imposed by modern life, intolerance and selfishness through especially the characters of Aydin, Necla and Nihal. Necla is especially pictured to expose Aydın's hidden face, contradictions and mistakes. The harsh and intense dialogues between them are the parts where the audience is informed with details. Necla who 
unceasingly criticizes Aydın, manages to reveal the weak sides and flaws of the male characters by her criticism, nevertheless, the criticism on her shows that she is not an affirmed character either.

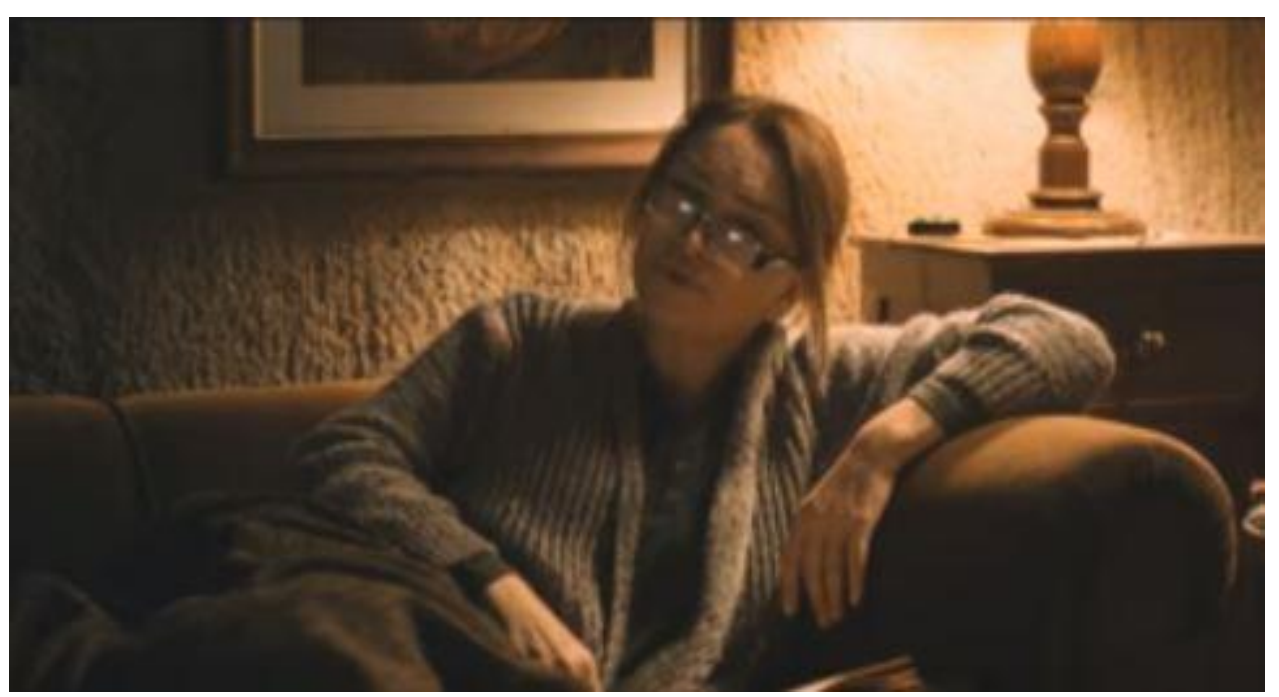

Image 5: Kış Uykusu (2014)

Necla is divorced from her husband and she still struggles with the questions about this divorce. She is a contradictory and pessimistic character and she judges Aydin and Nihal in a mocking and criticizing manner. With all her attitudes, all these senselessness she points out on the other sides reflects on herself as well. She gets offended easily, complains about everything. She is very intellectual like his brother in terms of realizing and stating other people's contradictions but totally ignorant in terms of knowing and facing wtih oneself. Necla who describes and blames Aydın for laziness, irresponsibility and fearing to face with himself, actually possesses all these attributes in herself and she avoids the face with it. The other person whom she always criticizes is Nihal. Necla finds odd the financial aids Nihal does with someone else's money without working and earning her own money, she figures her so to say a parasite.

Nihal appears as young beautiful but so to say, about to get lost in frustration. She is frustrated as a result of the pressure that Aydin tries to install on her with the aspects such as 
matureness, experience and knowledge. She forms the female side of a couple which are estranged and live in separate rooms. She tries to gather aids and overcome the needs of the schools that are in need via the community she involves thanks to financial possibilities of her husband. Through this way, she appeases her social needs with this community and she tries to accomplish something without Aydın, whom she is always shadowed by. Actually Nihal is the weak, poor and uneducated part of the story. What she does or tries to do are always belittled, disapproved and criticized by both Necla and the intellectual. Nihal in a sense is the part where the selfishness and mercilessness of the two powerful, rich and educated characters are reflected. She is also the regretful side of the relationship as she does not want Aydin to be in the organization she holds in the hotel, does not accept his offers for help and always appears with her sad and dull facial expression. She is desperate as much as she is regretful.

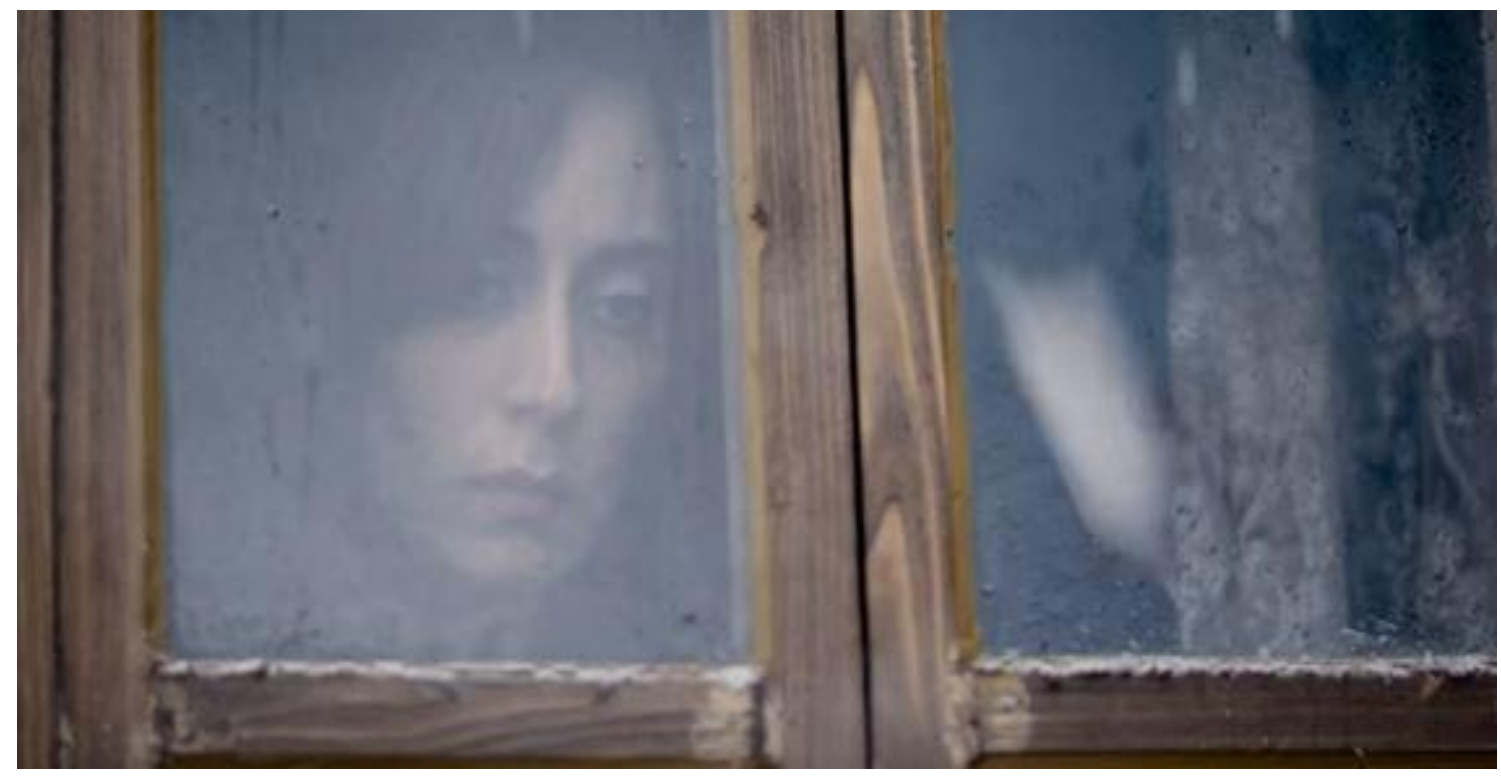

Image 6: Kış Uykusu (2014)

At the end of the film, the continuity of Aydın's life, how his personality would be shaped and what forms his behaviors get are all under Nihal's disposal. Aydın who leaves the hotel to go 
to İstanbul turns back and his subvocalized speech refers to Nihal. Aydın who says he could not go, he regrets and begs for mercy appears to put the burden and responsibility of everything that happens or likely to happen on Nihal who is already desperate under the burden on her shoulders yet who still struggles to hold on to life and accomplish something. And also the director may install upon Nihal the meaning that she is the only condition of Aydın's facing himself. Director clarifies the speech that Aydin subvocalized to Nihal at the end of the film:

That inner thoughts were supposed not to be understood whether to be told to Nihal or not. Are they just inner thoughts, inner intentions, spontaneous feelings; are they told to Nihal in some way or are they going to be told to her? Or is there a telepathically communication? Yet I supposedly balance the danger that what is being told is very clear and he may reveal too much his feelings, by bringing an ambiguity in his face that questions the sincerity of his words when he says "forgive me" in the end. When there is no other solution, 'if you can't beat them, join them'. You praise the other side because you cannot find another solution to relax yourself; only by doing that you can destroy what gives you shame. That we see a great relief in Aydın's face when he says the last words and we see that he finds the motivation to go back to work may indicate that he somehow gets rid of the heavy burden on his shoulders (Ceylan 2014).

Nihal's appearance behind the closed window is so to say the indicator that the drama would not end whatever the answer is. For Nihal the problem emerges from the fact that she cannot go rather than that whether Aydin goes or stays.

\section{Conclusion}

Nuri Bilge Ceylan is a creative director who brings a breath of fresh air in Turkish cinema with his minimalist perspective, distinctive narration and interesting stories. His name and films are known and remain in the agenda in world cinema as well as Turkish cinema and his success is awarded. His stories that were shaped by his own life or the pieces of the writers whom he was influenced 
managed to create their own audience over time. Ceylan, who seeks for different experiences starting from his first film and continued that in each time with successful films, also succeeded to challenge the commercial cinema and the stereotypical narrative forms that it imposes.

In Ceylan's films events are mostly shaped by individuals' life and relations and he generally picks men as the main characters. In his own words, he finds men's world more complicated and fragmented. The women are of course not irrelevant to these stories and relations. Since his films do not possess an urge to give a message or elements of political discourse, women are not very actively pictured in them. In his own words, he does not make films over women's problems or does not show favor to them. Women in his films are the secondary characters who are suppressed under patriarchal structure and male domination, who are weak, passive, and silent in their traditional roles or who are punished by male authority and social norms when they try to overcome these roles, who are prisoned by men behind closed doors if they are young and beautiful. The director who reflects the realities of life into the cinema actually gives place and role to women as they have in the life itself.

\section{BIBLIOGRAPHY}

Akbulut, H. (2008) Kadına Melodram Yakışır Türk Melodram Sinemasında Kadın İmgeleri, İstanbul: Bağlam Yayınları.

Aksoy, S. (2011) Son Dönem Türk Sinemasında Postmodern Kadın Kimliği, In Ö. Yılmazkol (Ed.) 2000 Sonrası Türk Sineması'na Eleştirel Bakış (pp. 225 - 252) İstanbul: Okur Kitaplığı.

Ceylan, N.B. (2011) "Meselem İnsan Denen Muammayı ve Onun Bağlı Olduğu Daha da Büyük Muammayı Anlamlandırmaya Çalışmak”. An Interview with Nuri Bilge Ceylan. Mithat Alam Film Merkezi Söyleşi ve Panel Yıllığı. Retrieved from: http://www.mafm.boun.edu.tr/files/768_7NBC.pdf (Accessed on 15 February 2016) 
Ceylan, N. B. (2003, May 1) “Sanki Herşey Kendiliğinden Oluyor Gibi...”, Sonsuzkare Dergisi, Say1:1, Retrieved from: http://www.nbcfilm.com/uzak/press_sonsuzkare.php (Accessed on: 01 March 2016)

Ceylan, N. B. (2014, July) Nuri Bilge Ceylan'la Kış Uykusu Üzerine, Retrieved from: http://www.altyazi.net/soylesiler/nuri-bilge-ceylanla-kis-uykusu-uzerine (Accessed on 07. March 2016)

Eren, N. (2008) Nuri Bilge Ceylan Filmlerinde Taşra ve Kent Tereddüdü (Unpublished Dissertation) Yeditepe University, Institute of Social Sciences: İstanbul.

Işık, M. \& Eşitti, Ş. (2015). Türk Sineması'nda Sıra Dışı Bir Kadın Karakter Olarak Aliye Rona. Kadın/Woman 2000, Kadın Araştırmaları Dergisi. Vol.16 no. 1, pp. 119-141.

Parsa, A. F. \& Akmeşe, Z. (2012). "Nuri Bilge Ceylan Sinemasında Anlatı Kodları ve Arketipler 'Bir Zamanlar Anadolu'da'", Paper presented at Sinemamızda Toplumsal Arketipler, Türk XIII. Film Araştırmalarında Yeni Yönelimler: Sinema ve Bellek Conference, International Conference of Kadir Has University, Communication Facutly, 03-05 May 2012. İstanbul.

Pösteki, N. (2005) 1990 Sonrası Türk Sineması, İstanbul: Es Yayınları.

Soykan, F. (1993) Türk Sinemasında Kadın, İzmir: Altındağ Yayınları.

Teksoy, R. (2007) Rekin Teksoy’un Türk Sineması, İstanbul: Oğlak Yayıncılık.

Ulusoy, N. (2011, September 16) Uzaktan Sevilesi Kadınlar, Retrieved from: http://www.radikal.com.tr/radikal2/uzaktan-sevilesi-kadinlar-1066638/ (Accessed on: 01 March 2016) 